\title{
Paying for Free Delivery: Dependent Self-Employment as a Measure of Precarity in Parcel Delivery
}

Work, Employment and Society

(C) The Author(s) 2018

Reprints and permissions: sagepub.co.uk/journalsPermissions.nav DOI: $10.1177 / 0950017018755664$ journals.sagepub.com/home/wes

\section{Sian Moore}

University of Greenwich, UK

\author{
Kirsty Newsome \\ University of Sheffield, UK
}

\begin{abstract}
This article explores supply chain pressures in parcel delivery and how the drive to contain costs to 'preserve value in motion', including the costs of failed delivery, underpins contractual differentiation. It focuses on owner-drivers and home couriers paid by delivery. It considers precarity through the lens of the labour process, while locating it within the supply chain, political economy and 'instituted economic process' that define it. Focus on the labour process shows how 'self-employment' is used to remove so-called 'unproductive' time from the remit of paid labour. Using Smith's concept of double indeterminacy the article captures the dynamic relationship between those on standard and non-standard contracts and interdependency of effort power and mobility power. It exposes the apparent mobility and autonomy of dependent selfemployed drivers while suggesting that their presence, alongside the increased use of technology, reconfigures the work-effort bargain across contractual status.
\end{abstract}

\section{Keywords}

dualisation, logistics, precarity, self-employment, supply chains

\section{Introduction}

Forming part of the logistics sector, parcel delivery work has expanded rapidly under the impetus of internet shopping and e-commerce and has become dominated by dependent

\section{Corresponding author:}

Sian Moore, Business School, University of Greenwich, Park Row, London SEI0 9LS, UK.

Email: S.Moore@Greenwich.ac.uk 
self-employment. Government figures point to a substantial increase in those considered self-employed, while recent Employment Tribunal (ET) cases involving Uber and City Sprint have exposed the fiction of 'self-employment' and the contradiction between contractual status and the high level of dependency and surveillance that characterises the work of the so-called 'self-employed' (ET, 2016a, 2016b). Despite these cases the Taylor Review of Modern Working Practices (Department for Business, Energy and Industrial Strategy (BEIS), 2017) declined to recognise the employment rights of 'self-employed' workers, highlighting the increase in their numbers, while celebrating the flexibility of the UK labour market. In comparison Field and Forsey exposed the 'Hermesisation'" of parcel delivery services and detailed the panoply of 'questionable working practices' that characterise the organisation of work (Field and Forsey, 2016: 3).

The reconfiguration of the supply chain has fuelled a burgeoning logistics infrastructure and myriad sub-contracting relationships and fissured workplaces (Weil, 2014). The requirement for more exacting, demanding and time critical levels of delivery results in an increasingly competitive market. The 'last mile of delivery' at the end of the supply chain is said to be the key to competitive advantage, with the costs of non-delivery crucial. The application of increasingly complex IT systems track and trace the movement of parcels under the watchful gaze of the employer and increasingly the customer. A European study exploring employment change in the parcel delivery sector highlights that liberalisation and de-regulation have resulted in far-reaching deterioration in employment conditions with increases in atypical employment, precarity and 'selfemployment' paid by piece-rate (Hermann, 2013).

Precarious work has become an umbrella term for a range of often undifferentiated 'non-standard' forms of employment to which contractual insecurity is central. Prosser (2016) has discussed precarious work in terms of competing theories of dualisation and liberalisation, whose application is country specific. Dualisation is the confinement of precarity to sections of the workforce (the periphery) with 'insider' actors complicit. Liberalisation, in contrast, threatens employment security and terms and conditions for all workers as a result of structural processes. Recalling the possibility of Fordism as exception and precarity as norm (Neilson and Rositer, 2008), this article conceptualises precarity through the lens of liberalisation, informed by Vosko's (2006) warning against dichotomising standard and non-standard work. It draws first on Behring and Harvey's (2015) 'instituted economic process' approach to explain the proliferation of 'selfemployment' in parcel delivery. They assert legal, fiscal and economic organisational processes as co-constitutive of the labour market within which employment status is defined (Behring and Harvey, 2015: 971). Fudge's (2017) discussion of the decline of the standard employment contract similarly points to the influence of institutional, fiscal and social policies, employer strategies and trade union responses. If these authors provide a wider political economy for dependent self-employment, Smith's (2006) conceptualisation of the double indeterminancy of labour - effort power and mobility power - allows a necessary link to the labour process. Here 'internal differentiation within the firm - segmenting jobs into different contracts' can be read as an attempt on the part of the employer to minimise the mobility power of internal labour (Smith, 2006: 399). The case of parcel delivery suggests that the use of 'self-employed' labour impacts upon both the mobility and workeffort bargain of directly employed drivers. At the same time the freedom of movement 
and control over the labour process that are implied by 'self-employment' is actually constrained; mobility and the organisation of work are subject to control - the double indeterminacy of 'self-employed' drivers is resolved in favour of the employer. For parcel delivery companies, self-employment may go some way to resolve uncertainties in the capitalist employment relationship and within the supply chain.

This article draws upon qualitative research exploring the impact of supply chain pressures on work and employment in the parcel delivery sector. The article first outlines the political economy of logistics, the liberalisation and privatisation of postal services and the changing nature of the UK parcel delivery sector. Second, it sets out the institutional framework, the growth in 'self-employment' and UK state support for it in the face of legal challenges. Research methods are detailed and the article then explores the evidence from in-depth interviews with directly employed and 'self-employed' parcel delivery workers in the context of three case study organisations. It illustrates the differentiated contractual status of labour as pressures are passed down the supply chain and the role of collective regulation in differentiation. It exposes the fiction of self-employment in parcel delivery and the way that dependent self-employment facilitates unpaid work, adding unpaid labour to extant dimensions of precarity. Finally it looks at the impact of the substitutability of labour on the mobility power of directly employed drivers alongside the work-effort bargain.

\section{The political economy of parcel delivery in the UK}

This study of parcel delivery in the UK is set in the context of the liberalisation of the postal service involving a change in the regulatory regime and ultimately (in 2013) the privatisation of Royal Mail. The third Postal Services Directive in 2008 required all EU postal markets to be opened to competition, and in the UK the Postal Services Act 2011 reflected that requirement. The parcels market has expanded in response to 'a revolution of e-commerce' (Ofcom, 2014) with Britain the biggest online shopping market in Europe (Financial Times, 23 November 2014). In 2013 products ordered online generated just over one billion deliveries; by 2018 , this number is expected to grow by $28.8 \%$ to 1.35 billion (Barclays, 2014). Turnover in the UK parcel market, dominated by Royal Mail, Hermes and Yodel, jumped 9.7\% in 2016 to 29.7 billion (Financial Times, 20 February 2017). Crucially intense competition means carriers receiving less for deliveries (Financial Times, 6 January 2016) with the communications regulator Ofcom finding that the average price paid to deliver a domestic parcel fell in 2015-2016.

The Financial Times (FT) (23 November 2014) has reported that 'faster delivery times have become a critical issue for postal operators and retailers', with the success of DPD (owned by France's La Poste) in increasing its parcel volumes due, at least in part, to its delivery technology - a nationwide seven-day service that uses GPS technology to give customers a one-hour delivery window and lets the company track the driver en route. As important as delivery times is the issue of failed deliveries, with first-time delivery vital to competitiveness and the onus on the company to deliver rather than the customer to be home. For the $F T$ this issue has not been effectively resolved, with repeat deliveries representing real costs for companies and a spokesperson for Deutsche Post reporting that it can take three delivery attempts before a parcel is received (Financial 
Times, 23 November 2014). Barclays' report on the sector confirmed that the biggest issue facing logistics firms is delivering goods when recipients are not present and that over $63 \%$ of carriers stated this as a concern (Barclays, 2014).

More critical contributions have sought analytical purchase on the dimensions of the logistics transformation and their impact on labour. Logistics, Hesse and Rodrigue (2006) argue, supports, shapes and provides coherence to global production networks with its scope and remit operating beyond the simple storage and delivery of goods. Harvey et al. (2002) extend this argument by highlighting new conflicts over the capture of added values generated by fragmented supply chain relationships. They suggest that retailers/clients not only reconfigure relations under their exacting patronage, but simultaneously orchestrate competition among third party providers (3PL) as a mechanism to maximise efficiency and drive down costs. As a result, contracts between retailers and parcel delivery providers are short-term, contingent and transparent - creating a quasimarket - controlled by client organisations with costs (non-delivery and damage) defrayed to providers. There is a growing body of research evidence that focuses on the implications for labour and collective regulation of this 'contested terrain' between retailers and logistics companies (Coe, 2014). The 'labourers of movement' (Cowen, 2014) find themselves within a 'perfect storm' of globalisation, fragmentation of production, fissured workplaces, new logistics technologies and eroded collective regulation (Coe, 2014; Flecker et al., 2013; Newsome, 2015). It is parcel delivery workers, at the end of the supply chain, who experience the effects of acute cost minimisation. To date there is little research evidence exploring how this cost minimisation is articulated through the contractual status of workers.

\section{Precarity and parcel delivery in the UK}

Following the 2008-2009 recession, self-employment has been a main source of UK employment growth. Tomlinson and Corlett (2017) estimate from Labour Force Survey data that it accounted for $45 \%$ of the growth in total employment from the second quarter of 2008 to the final quarter of 2016 when it totalled 4.6 million or one in seven of the workforce (15\%). Although the category is diverse, solo self-employment predominates, as relatively few self-employed workers have employees (Hatfield, 2015). Self-employment removes employment rights and employer obligation to workers, transferring risk and the social costs of employment (sick pay, holiday pay and pensions) to the worker.

Studies of the construction sector demonstrate the prevalence of false or bogus selfemployment (Behring and Harvey, 2015). Similarly, self-employment in parcel delivery is marked by many characteristics of direct employment, in terms of continuity of engagement with a single employer and control over working time and the labour process. The fiction of self-employment was exposed in two legal cases in 2016. In Aslam and Farrar v Uber (ET, 2016a), two drivers supported by the GMB union brought claims under the Employment Rights Act 1996 and National Minimum Wage Act 1998 over the failure of the company to pay the minimum wage and to provide paid leave. Uber claimed that the drivers were not workers and thus not entitled to protection under the legislation. However, the ET found that the drivers had a dependent work relationship with Uber, not 
least because the company instructed drivers how to do their work and controlled them in the performance of their duties (Uber lost an appeal against the decision). A similar case concerned CitySprint (ET, 2016b), where it was judged that a bicycle courier should be classified as a worker and not an 'independent contractor' and had a right to paid holidays. Here it was deemed that the regulation by the employer of the amount of work available, performance of the service and of the size of the workforce were indications of direct employment. She was considered to have no real right to appoint a substitute (to take her place when she was not available for work). The issue of 'substitution' arose again in the case of Deliveroo, with a divergent outcome. In November 2017 a claim for union recognition for collective bargaining for Deliveroo riders failed on the basis that they were judged to be 'self-employed' because of their apparent freedom to 'substitute' allowing other riders to take their place on a job (Central Arbitration Committee, 2017). For Managing Director, Dan Warne, this was 'a victory' for the flexibility that selfemployment provides (BBC, 2017). Rights to the National Living Wage (NLW) were tested in the referral of Hermes to HM Revenue and Customs. The company maintained that the self-employed status of the couriers removed its legal responsibility to ensure they were paid the NLW, while the Guardian reported that the sums paid to couriers amounted to less than the hourly NLW (Booth and Osborne, 2016). The subsequent investigation promised to shed light on how far classifications of self-employment are misplaced and the extent to which employers were using self-employment to circumvent payment of the NLW.

The research presented here is concerned to understand the changing contractual status of parcel delivery workers in a way which moves beyond dichotomised precarious and 'standard' work contracts (Kalleberg, 2012). This involves an approach which embeds an understanding of precarity in political economy but with sufficient fluidity to explore its dimensions and dynamics at the level of the workplace, embracing the labour process and role of labour as agent (Strauss, 2017). Behring and Harvey's notion of degenerative and instituted competition between 'different qualities and types of labor' is resonant (2015: 972). Exploration of the differentiated labour process of directly employed and 'self-employed' drivers allows reflection on Smith's (2006) concept of the double indeterminancy of labour. Here labour mobility is one element of labour indeterminancy. Since self-employment is theoretically posed as a form of mobility - freedom of the individual to dispose of their labour (Thompson and Smith, 2009) - the labour power of self-employed workers is potentially expanded. At the same time, Smith's (2006) argument suggests that the use of self-employed workers increases the substitutability of directly employed labour in order to manage their mobility. This points to a dynamic relationship between self-employed and directly employed workers, but also 'between the indeterminacies around mobility power and effort power' (Smith, 2006: 399). A double-edged double indeterminancy arises, since for both groups of workers the second element of indeterminancy - effort power - is contested and constrained by the 'employer', in part through the fiction of the mobility power of 'self-employed' workers and in part through the technological control of performance - with the latter belying the status of 'self-employed' workers.

Drawing on this contextual and conceptual framework the research responds to Vosko's emphasis on a multifaceted approach to elaborate how dimensions of precarious work at 
a macro level play out in practice (2006: 16). The concern is to explore how supply chain and cost pressures in parcel delivery have produced differential contractual statuses and to explore the construction of precarity through the lens of the labour process.

\section{Research methods}

The article is based upon the findings of a research project concerned with exploring the working conditions of parcel delivery workers at the end of the supply chain. Qualitative research methods were adopted, focusing upon three case studies. Seven initial 'scoping' interviews were undertaken with national and international trade union officers; three from Unite, two from the Communication Workers Union and two from Uni-Global and the International Transport Workers Federation. Following these initial interviews case studies of three national companies were undertaken, selected to reflect varying organisational typologies with different models of contractual status to allow comparative analysis (Table 1). Company $\mathrm{A}$ is a former state-owned enterprise and is unionised with terms and conditions of employment regulated by collective agreements. Within this case study 12 interviews were conducted with depot managers, supervisors, trade union representatives, directly employed delivery workers and owner-drivers. The second case study, Company B, is part of a US multinational and is also unionised, with terms and conditions collectively negotiated. Access to this company was more problematic, but eight interviews were secured with full-time union officials as well as directly employed workers and owner-drivers. Finally, interviews were undertaken with six home-based couriers in Company $\mathrm{C}$, a national organisation that is non-unionised and operates with both owner-drivers and home couriers. Interviewees from all case studies were able to reflect on the introduction of, rationale for and impact of owner-drivers and couriers in the organisations and in Company $\mathrm{A}$ and $\mathrm{B}$ on the role of collective regulation, capturing

Table I. Interviews.

Interviews

\begin{tabular}{llllll}
\hline Depot managers/ & Trade & Directly & Owner- & Home & Total \\
supervisors & union reps & $\begin{array}{l}\text { employed } \\
\text { drivers }\end{array}$ & drivers & couriers & \\
& & & & \\
\hline
\end{tabular}

Key informant trade

7 7 union interviews

Company A 5 3

4

3

Company B

Company $\mathrm{C}$

Additional in-depth

dependent 'self-

employed'

Additional

10

interviews with

home couriers

Total

10

6

I I

17 
changes in the delivery labour process, and the terms and conditions of both 'selfemployed' and directly employed drivers. With the exception of one female home courier all interviewees were white males. Triangulation was provided by documentary and web analysis of company policies and trade union agreements. The research was subject to ethical approval and all interviews were face-to-face, recorded and transcribed and based on informed consent with confidentiality and anonymity guaranteed.

Owner-drivers and home couriers are necessarily difficult to locate since they have few formal organisational ties. Their working hours and time pressures mean that achieving in-depth interviews is problematic. In addition to the case studies five in-depth interviews were conducted with owner-drivers who had worked for seven key parcel delivery players in London, four of whom were black males. Here a snowballing technique was deployed, since, while they worked for different organisations, these drivers had moved between them and retained networks. These interviews took the form of work histories, focusing on the motivation for self-employment, the delivery labour process, technology, work intensity, terms and conditions, pay and hours. Direct drivers also had experiences of working 'self-employed' for a range of providers and where interviewees talk about specific (non-case study) companies in their testimonies they are referred to as companyl, company 2 and so on - overall five companies in addition to the three case study organisations are covered. In addition to these in-depth interviews 10, 10-minute interviews with home couriers while on delivery were secured. They were approached when they were waiting on door steps and asked a limited number of questions, generally confined to volumes of deliveries, hours and pay. The respondents were all male and half were migrant workers. A more in-depth interview was conducted with a young female courier from another of the key national players. The home courier interviews are supplemented with data from posts on two public on-line forums where there have been threads discussing 'self-employment' at two delivery companies. In ethical terms the inclusion of these data reflects the tenets of British Sociological Association (BSA) Guidelines on Digital Research (2017) that it is generally accepted that there are exemptions to informed consent where research takes place in public space or makes use of publicly available information; posts were already anonymised and those posting could not be identified.

Online posts, transcriptions and documentation were subjected to micro-level critical textual analysis to identify worker experience and perception, with macro-analysis illuminating how the political economy of parcel delivery promoted the wider social-political practices that shaped and contextualised the texts (Roper et al., 2010). The analysis drew on aspects of the staged panel approach advocated by Biographical Narrative Interpretive Methods in that interpretations were articulated and discussed collectively to uncover researcher subjectivity and intellectual positionality (Moore and Ross, 2016).

\section{Contractual differentiation}

The evidence pointed to the emergence of three tiers of contractual status driven by competitive and cost cutting pressures and producing different levels of precarity. The first tier covers directly employed drivers in large parcel delivery companies covered by extant collective agreements, which may have been renegotiated in the context of the pressures brought by service-level agreements, but which provided some guarantees for 
a long-standing organised workforce. The second tier involved the introduction of a tier of technically 'self-employed' owner-drivers who lease or own their vans and were generally paid by delivery. They could work through small contractors, but were based in depots and worked alongside directly employed drivers. A third model was of homebased couriers (referred to by direct drivers as 'life-style' couriers - since work was seen to be organised around other commitments), also technically self-employed, but using their own cars with very limited organisational ties and no fixed workplaces.

The research evidence suggested three corresponding typologies of parcel delivery company, characterised by the particular mix of directly employed, owner-driver and home-based couriers. Importantly, these typologies reflected the collective regulation of work. In Company A a 'mixed resourcing agreement' specified the proportions of ownerdrivers that could be utilised on a depot-by-depot basis. Company B, similarly, had established ratios of directly employed delivery workers to owner-drivers as part of their collective agreements. While directly employed workers predominated in Company A, low cost entrants to the market such as Company $\mathrm{C}$ were dependent upon neighbourhood delivery with no union recognition. Union members in both Company A and B recognised that policing collective agreements in terms of monitoring ratios of self-employed to directly employed drivers was part of defending the frontier of control.

For Vosko (2006) the removal of employment protection is a key indicator of precarity. Similarly, Fudge argues that contractualisation facilitated the commodification of labour (2017: 376) and the move away from the standard employment relationship involves employers jettisoning the social costs of labour with risk transferred to the individual worker. In the UK self-employment precludes employment rights, with no safeguards on hours and breaks and the cost of holidays and sickness borne by the workers themselves. In Company A owner-drivers were contracted to provide a service 52 weeks and 365 days of the year. As in other companies, if an owner-driver took holiday or was sick it was their responsibility to find a substitute to cover their work and if they could not do so they incurred the costs of the Company funding an agency worker and possibly a fine. The difficulties of finding cover meant one Company A owner-driver had not taken holiday for three years, while a respondent who was directly employed by Company $B$ recalled his experiences of being an owner-driver with City Link (which subsequently went into administration) and the difference direct employment made:

It's really nice coming back especially after Christmas and Easter and holidays. You go away for two weeks and you go 'Look, I've actually got money in the bank.' It was really hard before, you had to employ someone for two weeks and then if they couldn't do it the company'd go 'Sorry mate, I've had to put a courier on top of your round with your bloke', and then you'd get billed for it. So you might actually come back from holiday and work another month for no money because you'd got to pay for the courier, which is why I think people tend not to have holidays when they're self-employed. When I was an owner-driver at City Link if you phoned in sick they might have to put three couriers on your route and you'd come back and you'd get a bill for like $£ 900$ and it'd wipe your money out for a week. So you didn't go sick. (Direct Driver, Company B)

An owner-driver for company 2 reported being deducted $£ 150$ per day when sick to fund cover. Home couriers in Company $\mathrm{C}$ similarly stated that they were required to find cover 
for their routes if they wanted to go on holiday or they were sick and failure to do so resulted in fines and/or the removal of delivery routes. Respondents recalled instances where the company had reduced the volume of parcels from couriers if they failed to deliver required rounds irrespective of circumstances, including serious illness and bereavement.

\section{Indeterminancy, the myth of mobility power and autonomy}

Vosko (2006) asserts that definitions of precarity cannot be rigidly applied across all forms of non-standard work. While precarity implies insecurity, evidence suggests that owner-drivers had, in Smith's (2006) terms, mobility power and its requisite resource requirements in terms of networks and labour market demand. They shared labour market intelligence and appeared to move easily between delivery companies - all of those interviewed had worked for a number of different companies and were highly aware of the terms and conditions in the sector. A depot manager commented:

Right now wanting to join me I've got maybe two from company1, there's three or four from company2. Well, this is what happens. I got one guy from company2 and then he's told all of his mates at company2, 'Oh, it's better and it's more money and it's more relaxing and you get out a lot earlier' so then all of his mates follow and that just as easy could happen with us somewhere else. One of our guys could go to companyX and say 'Oh, it's better over here.' When we came here we took a load from company1, about six or seven, and there's a load that have come from company2. So it happens between all competitors and they all speak to each other as well. So my guy that's there on one route, he will know by name the company2 driver out there, the company3 driver out there, the companyY driver out there. They all speak to each other. (Depot Manager, Company A)

The labour turnover of owner-drivers appeared to be relatively high and the increased demand for home delivery promoted mobility. Delivery offered accessible work for largely male workers, although owner-drivers emphasised that its intensity and hours were probably unsustainable for older workers and workers with families. Van or lorry driving has been associated with freedom and a degree of autonomy over the labour process (Levy, 2015) which may be enhanced by self-employment, as a company4 driver commented:

That's why I love my work, this job, because you're on the road and you do it at your own pace, you see? And it's only when they need something from you, they either phone you or message you. That's it. (Owner-driver, company4)

One aspect of the debate over 'self-employment' reflected in the Taylor Review (BEIS, 2017) is worker preference and drivers expressed the view that driving can offer relatively high earnings for workers with limited accredited skills. One company 2 ownerdriver who had also worked as a shift manager for company5 suggested the contradictions while pointing to variation between owner-drivers and home couriers:

The people who were home couriers for both company 5 and company6 were undertrained, underpaid, under motivated, you can't put too much expectation on them. Whereas I did 
$£ 40,000$ in my first year as a driver with company 2 - well to my mind for a bloke with no skills and very little in the way of, I mean I'm not stupid, but I've got no qualifications, I can't go into a profession, but to earn 40 plus grand a year unskilled, that's a good wage. And I think that is borne out in the way the company operates. It's got the means to pay a bloke like me 40 grand a year because it will get every pound of flesh out of me it can, but it will be worth it for me - I mean it's not perfect, but ... (Owner-driver, company2)

While self-employment appears to enshrine mobility power and autonomy over the labour process once in the van, the comment of a depot manager for Company A implied the tenuous nature of the definition of owner-drivers as self-employed:

You've got to ensure that you're not giving the impression they are employees because they're not. So you've got to treat them as contractors. They are a resource. They work for themselves, they don't work for us. They're contractors. We give them the parcels and they work for themselves. They're businessmen, aren't they? (Manager2, Company A)

However, the increasing stipulations as to how and when owner drivers and home couriers completed their daily tasks were of growing concern to respondents. Management control over the allocation of work and thus drivers' capacity to earn operated as a disciplinary mechanism with the threat of removing parcels used to secure compliance, as for one home courier:

They threaten you, you either do it or you're out. It's that kind of environment. You live in threat of them saying, no parcels, that's it. It's awful to think, that after doing 10 years for them, doing all the hard work, building a round up for them, they go 'see you later'. You've got nothing, and that's what they threaten you with. All the time, 'we'll just take your parcels'. Everything you do wrong now, they say, 'oh well you know we can suspend your parcels'. (Home courier1, Company C)

At the same there is close monitoring and surveillance of work through the hand-held Personal Digital Assistants (PDAs) that electronically track and trace the movement of goods, but also the movement of both directly employed and self-employed labour. Home couriers in Company $\mathrm{C}$ were required to send customers 'estimated time of arrival' (ETA) texts, accommodating requested delivery slots during mornings, lunch-times and afternoons. The company was unrelenting in its expectations that delivery slots be adhered to and failure to do so risked drivers being placed on 'improvement notices', as another home courier reported:

The rules have changed, you have to adhere to what they want. You have to set ETA to how you feel that you can deliver your round, but you have to incorporate their a.m., their midday, and their p.m.'s. I recently had an email stating, 'Yes, you are self-employed, but you have to adhere to what we ask you to do.' There is the tracking, the proper receipt scanning outside of doors, as many signatures as possible. You're not self-employed - now it's, 'You must, you must, you must, you must ...' (Home courier2, Company C)

In the ET case taken by a City Sprint courier (referred to earlier) the fact that the claimant was tracked by GPS technology and wore a company uniform contributed to 
the judgment that the assertion of couriers as self-employed was 'window dressing' (ET, 2016b). In parcel delivery it was similarly clear that, although drivers were technically self-employed, managers dictated how drivers did their work and controlled performance. Owner-drivers reported that depot managers applied pressure to ensure that deliveries were made on time, with drivers not delivering their allocated load subject to fines. Despite having apparent mobility and with labour effort secured through incentivisation by delivery rates, the organisation and pace of work was closely managed. For both self-employed and directly employed drivers technology increasingly drove work effort.

\section{Payment by delivery: Unpaid labour}

While directly employed drivers had fixed hours and hourly rates, owner drivers were paid by the number of deliveries or drops. The key advantage of owner-drivers for the companies was the removal of the costs of non-delivery, effectively excising apparently non-productive or 'dead' time. In Company A directly employed drivers had a target of 70-80 drops within a fixed working day, but owner-drivers were initially paid by delivery for 100 drops per day, targets that increased in the following year to 120 drops and in the year after to 130 drops. For a depot manager ownerdrivers provided the flexibility to meet demand and offset risk: 'Owner-drivers need to do more work to make it pay. That's why they're more efficient, because they need to do one and a half times more than a [Company A] driver to make it pay' (Delivery Manager, Company A).

Owner-drivers in Company A were reported to receive $£ 1.65$ per parcel delivery stop and $£ 2$ for collections or pick-ups. An owner-driver for company2 in London had earned $£ 1.79$ per delivery on a residential route with about 130 stops per day. He was then moved on to a business delivery route at a higher rate of $£ 2.10$, with fewer stops (72 on the day of the interview). Directly employed drivers were reported to be on between $£ 8$ and $£ 8.50$ per hour. While in some companies owner-drivers were given more condensed delivery areas as driving longer distances without pay would not be financially viable, in others it was reported that they were allocated rural routes 'to take the hit' of non-productive driving time or 'dead mileage'. Although pay for owner-drivers was perceived as relatively high there were signs of deterioration in delivery rates. Drivers reported that they would be contracted on one delivery rate, but after some time companies would attempt to reduce the rate or increase targets, as one union rep who had worked as an owner-driver for company2 reported:

With company2 they give them a contract and then when it comes to near the end of the 18 months or the two year contract or 12 month contract, whichever one they've got, they'll decrease the rate and increase their targets and they'll say 'Well, I can't make money on that.' 'It's not our problem', they say. The rate was really good when I started as an owner-driver and then they just chiselled and chiselled and chiselled away and then in the end they were going 'Well you were earning $£ 1400$ a week.' 'Yeah, but I'm doing the hours.' 'But we don’t want you to earn more than $£ 1100$ ', but when you take out the van cost, the diesel cost, the insurance, your uniform and everything else you're probably working for about $£ 4$ an hour. (Union Rep, Company B) 
While rates may look relatively high a range of costs have to be deducted. Ownerdrivers owned or rented their own vans, although in Company B they could lease them and the company deducted lease costs (around $£ 450$ per month) and diesel costs from pay. Owner-drivers were responsible for tax, national insurance, business liability and goods in transit insurance, as well as for uniforms and the costs involved in wear and tear and damage to their vans (and renting another van when off the road).

Rates per drop for home couriers in Company $\mathrm{C}$ varied from $85 \mathrm{p}$ per standard parcel to $£ 1$. They reported that wage levels were unpredictable and that low volumes of parcels would not generate sufficient income for drivers to reach NLW levels:

You're talking insecure work when you don't how many parcels are coming. I could get up tomorrow and I could have a hundred, that's a good day's work, I'll be above minimum wage. I could also get up, and have 10. So, every day, you're worrying, basically. Or you're conscious of how much am I going to make? I know for a fact today, by doing the miles that I have to do, the times and everything, I'll be lucky if I even touch $£ 5$ an hour. (Home courier3, Company C)

Further, payment by actual delivery excludes time spent organising work, travelling between drops and failed deliveries, blurring the boundaries between paid and unpaid time (Supiot, 2001). For home couriers the demarcation between work and home was also unclear since parcels were dropped to their homes and between one to two hours daily were spent sorting parcels into delivery rounds, scanning them into the system and downloading the 'manifest' which dictated the delivery route. If all the parcels were accounted for (which was often not the case, necessitating further phone calls) parcels could then be loaded on vehicles. Couriers then sent texts to customers informing them of their ETA, although the capacity for customers to demand delivery slots meant that drivers had to recalibrate their accustomed and often cost-effective delivery routes. These essential activities are all unpaid. In the case of company5 home couriers posting on a forum reported that they received as little as $50 \mathrm{p}$ per delivery or collection, and could deliver up to 30-60 parcels per day covering a three mile radius taking between two and four hours. As one posted:

So we can assume based on 2 hour delivery time $30 \times 50 \mathrm{p}=£ 15$. Not too bad for 2 hours work eh? Let's think about that -15 parcels in 60 minutes or 1 parcel every 4 minutes. While taking into account driving from address to address, waiting at door, people not being home, finding a neighbour that is, or finding secure location to leave it. Not to mention re-delivery of items, of which you have to make three attempts in order to receive your 50p. This is not taking into account fuel expense and vehicle wear and tear, business insurance which you have to pay yourself. I think it's safe to say that with the time it takes to plan your route and deliver 30 parcels having to re-attempt delivery etc., you're looking at around 3-4 hours, based on one parcel every $6-8$ minutes. That's just $£ 3.75$ to $£ 5.00$ per hour! Take off your fuel, say $£ 5$ (and that's being generous) and you're looking at $£ 2.50$ to $£ 3.33$ per hour. (Home Courier, company5, online)

Another incisive post stated, 'I suppose someone has to pay for "free delivery" - just rather it wasn't me.' Owner-drivers in Company A also reported levels of unpaid labour within the working day. Here the distinction between paid and unpaid working time is 
exposed acutely when drivers return to the depot at the end of the day for unloading. A directly employed driver hinted at possible tension between directly employed and owner-drivers:

I was telling you about the queuing in the evenings. Well, they're not paid on an hourly basis. So if I'm sat outside there for an hour every night queuing up, then I'm clocking it on as overtime. They're not paid overtime. They're paid on a per drop basis, so there is an issue with them whereby they're petitioning that there should be two doors open in the evening - one where owner-drivers can just drive in and drop off their parcels and the other one where employed drivers would queue - which I can understand, to be honest with you, because if they're not getting paid for that time and they've got to sit out there for an hour and a half then I can see, but I don't think you'd find too many Company A drivers taking too kindly to sitting in a queue while other people effectively queue jump. (Directdriver1, Company A)

Owner-drivers reported being in the van 12-13 hours daily. One working for company 2 recounted that he would arrive at the depot to load his van at 5 a.m., finish his deliveries by 2.30 p.m., but then had to wait in the van to make a scheduled collection at 4 p.m., returning to the depot to unload collections and failed deliveries and finally leaving at 5 p.m. This 'waiting time' means the worker is effectively available to the employer, but not paid. He also described how payment by delivery encourages the intensification of work. Since scanners were set for a default of four minutes per stop, arrival within four minutes meant drivers have 'dead time' before the next stop. To strip out this time drivers set their scanners to a lower stop time in order to finish quicker and maximise money:

So what happens is you put yourself on really low minutes which may be one minute a stop so you're driving quickly just getting there, but it's making your day shorter. So there is actually pressure to be quick because you don't want to be out till 8 o'clock. You want to finish, have a life, go home, but you also want to take out a lot of parcels to earn money. (Owner-driver, company2)

\section{The substitutability of labour}

The use of owner-drivers served to minimise the mobility power of existing workers. A directly employed driver expressed insecurity at their introduction:

In my instance I didn't realise that my job could go to an owner-driver, to a self-employed. I just thought that every route driver's job was safe. I don't know how many owner-drivers are allowed in this depot, so you never know. They could be looking for two or three now to do it which they'd have to obviously move somebody off their route or split it up. I don't know that side of it but, like I say, when I first heard about it I thought 'Well, surely they're not allowed to do that?' I just thought after the years I've worked here my job's not even safe? (Direct Driver2, Company A)

A driver who had worked for City Link reported that the company had threatened drivers that they would lose their routes if they did not move to self-employment and eventually offered an incentive in the form of a small contribution to the purchase of vans. In Company A a small number of directly employed drivers had moved into 
self-employment (including some dismissed by the company). Another owner-driver alluded to the potential displacement of directly employed drivers, reporting that deliveries and routes may be passed between owner-drivers and the directly employed and he noted the importance of securing and holding onto routes that guaranteed income:

[The] next thing they're saying to me, because they've got loads of employed drivers that they wanted to get rid of but they couldn't get rid of them because they've got a lot of rights, they were like we need to give these guys work, so they said to me 'You've got to give 20 of your stops to the employed.' Twenty stops is my work, my money that I'm making and basically you're taking money from me and giving it to the employed who are getting paid anyway. So I was thinking that's a bit funny and I was going to kick off a stink about that when I thought, do you know what, I don't want them mucking about with my route. Let me just co-operate. (Owner-driver, company2)

The presence of owner-drivers also impacted the work-effort bargain within the organisation and the capacity of directly employed workers to struggle over it informally and formally. A union officer commented on the role of the trade union in acting as a break on work intensification for the directly employed, but this was in the shadow of 'rate busting' by owner-drivers:

Whereas within the collective in-house we can keep a good discipline on these things - I'm not saying a go-slow - but there is a limit with regard to safety and quality of delivery, but this is what is being introduced alongside people directly employed who may be doing on average 70-80 in comparison to 100 drops per day under this blueprint agreement in this franchised model which is directly undermining on two levels; one, you're getting paid less doing more and also taking half as much away from the normal driving workforce. So we've had direct conflicts because of that. (Union Officer)

Despite collective regulation a union rep suggested the implicit threat represented by owner-drivers may have led to direct drivers coming into work earlier than necessary and potentially normalising unpaid labour:

Some of them [direct drivers] on a morning for their own benefit sometimes will come in early, earlier than what their start time is to get ahead of themselves. They don't get paid for it. They probably come in at half-six, but they don't get paid, but they're still doing bits. Then it's the same when they're out delivering, because you're driving you should have a break now and again; some won't have a break, some won't have a dinner. They'll work through all their workload just to get done, but they'll come back early. I can't weigh it up myself. I don't know why they do it. I've always been a man if you get paid from seven you start at seven; if you finish at five you work till five and no matter what you've got in between them hours. (Union Rep, Company A)

The evidence suggests that the introduction of self-employment was creating insecurity among directly employed drivers and pressures on existing collective agreements. While both owner-drivers and directly employed reported limited interaction between the two groups in the depot, there was apparently no intention by the unions concerned to recruit or represent self-employed drivers. While such organisational tension has been used to testify to dual labour markets (Palier and Thelen, 2010) the evidence suggests a more dynamic relationship. As a result of growing work pressures, home couriers in Company $\mathrm{C}$ were 
considering the possibility of trade union organisation. Media attention regarding bogus self-employment and resulting legal cases provided motivation, as illustrated by one courier who argued, 'Being self-employed means self-employed. We work to our own rules, and our own timing. We're supposed to decide when we work, not them.'

\section{Conclusions}

This article reveals how intense supply chain pressures in a highly competitive parcel delivery market have produced differentiated contractual status and how reconfigured contractual status is integral to cost cutting, the speed-up of delivery and, crucially, the removal of non-delivery costs. It locates dependent self-employment firmly within the political economy of logistics and a national institutional framework that legally and fiscally promotes self-employment, Behring and Harvey's (2015) 'instituted economic process', while exposing the fiction of 'self-employment'. Legal cases have potentially far-reaching implications for the legal and fiscal basis of 'self-employment' in the UK and have demonstrated the potential for the collective organisation of those on non-standard contracts, sometimes in the face of the intransigence of existing unions. The government's Good Work Plan, its response to the Taylor Review (HM Government, 2018), suggests that it will deliver little in terms of rights for such workers. The outcome of the Deliveroo recognition case did not bode well, but the decision of the Supreme Court in the case of Pimlico Plumbers (The Guardian, 2018) was expected to set a precedent.

The articulation of political economy and labour process allows for exploration of the different facets of 'self-employment' including, in terms of employment rights, the transfer of responsibility for social costs such as sickness, holiday and pensions to the individual worker. Examination of the labour process uncovers parcel delivery companies' de facto control over the work of owner-drivers. The testimonies of self-employed drivers are resonant with Harvey et al.'s (2017) suggestion that such contractual relationships may give rise to the over-estimation of, not only autonomy, but income. A labour process focus exposes how dependent self-employment allows for the excision of periods of working time from the remit of pay, in particular through the removal of the costs of nondelivery. Research on zero-hours contracts in homecare (Moore and Hayes, 2017) has similarly shown how non-standard contracts can strip so-called 'unproductive' labour from paid work and, as in parcel delivery, can allow employers to accommodate the NLW. This article makes a case for the inclusion of unpaid labour as a dimension of precarity.

The article supports Crouch's assertion that core and peripheral workers 'exist alongside and in tension with each other' and the emergence of groups of 'outsiders' is a result of this interaction (2015: 29). It is important to recall that the debate over dual labour markets has prevailed over 30 years and Pollert (1988), in this journal, cautioned against an ahistorical analysis and any model that asserts that segmentation is a departure from a previously homogeneous internal market. Rather she emphasised sectoral restructuring and change alongside generalised attacks on working conditions characterised by work intensification and rationalisation. The growth in non-standard contracts has further shifted the balance of power in the employment relationship (Fudge, 2017).

This article has responded to Smith's (2006) call for further work on the balance between indeterminacies for different groups of workers and employers and how 
mobility power shapes the labour process under different forms of capitalism. In the context of dependent self-employment it suggests that Smith's double indeterminacy is also double edged. The presence of owner drivers and home couriers undermines the mobility power of directly employed drivers, but also reconfigures the work-effort bargain in favour of the employer. At the same time, while self-employment is apparently a manifestation of mobility, for owner-drivers the freedom of movement and control over the labour process that is implied by this contractual status is constrained. Despite the apparent contradictions of 'double-double indeterminacy', the reality of the dependence of self-employed drivers, as constructed through instituted economic processes, suggests resolution for capital.

\section{Acknowledgements}

We are extremely grateful to all those who spared time to speak to us as part of the research and to the referees and editor for their insightful comments.

\section{Funding}

The research is part of wider research funded by a small British Academy/Leverhulme grant.

\section{Note}

1. The report records the work experiences of couriers working for Hermes.

\section{References}

Barclays (2014) The Last Mile: exploring the online purchasing and delivery. Available at: https:// www.barclayscorporate.com/content/dam/corppublic/corporate/Documents/research/Thelast-mile-report.pdf (accessed 22 January 2018).

BBC (2017) Deliveroo claims victory in self-employment cases, 14 November. Available at: http://www.bbc.co.uk/news/business-41983343 (accessed 15 December 2017).

Behring F and Harvey M (2015) The evolution of false self-employment in the British construction industry: a neo-Polanyian account of labour market formation. Work, Employment and Society 29(6): 969-988.

British Sociological Association (BSA) (2017) Ethics Guidelines and Collated Resources for Digital Research, Annex to BSA Statement of Ethical Practice for the British Sociological Association. Available at: www.britsoc.co.uk/ethics (accessed 22 January 2018).

Central Arbitration Committee (2017) Available at: https:/www.gov.uk/government/uploads/system/ uploads/attachment_data/file/663126/Acceptance_Decision.pdf (accessed 11 December 2017).

Coe N (2014) Missing links: logistics, governance and upgrading in a shifting global economy. Review of International Political Economy 21: 224-256.

Cowen D (2014) The Deadly Life of Logistics Mapping Violence in Global Trade. Minneapolis, MN: University of Minnesota Press.

Crouch C (2015) Labour market governance and the creation of outsiders. British Journal of Industrial Relations 53(1): 27-48.

Department for Business, Energy and Industrial Strategy (BEIS) (2017) Good Work: The Taylor Review of Modern Working Practices. London: Department for Business, Energy and Industrial Strategy.

Employment Tribunal (ET) (2016a) Aslam and Farrar V Uber. Available at: https://www.judiciary.gov.uk/wp-content/uploads/2016/10/aslam-and-farrar-v-uber-reasons-20161028.pdf (accessed 10 December 2017). 
Employment Tribunal (ET) (2016b) Dewhurst V City Sprint. Available at: http://www.bwbllp. com/file/judgment-pdf (accessed 10 December 2017).

Field F and Forsey A (2016) Wild west workplace self-employment in Britain's 'gig economy. Available at: www.Frankfield.co.uk (accessed 22 January 2018).

Financial Times (2014) DPD seeks to put Royal Mail under further pressure with hiring. Financial Times, 23 November. Available at: https://www.ft.com/content/724c47d2-70e4-11e4-85d500144feabdc0 (accessed 22 January 2018).

Financial Times (2016) Online orders boost UK parcel market. Financial Times, 6 January. Available at: https://www.ft.com/content/85c03ea8-b3ab-11e5-b147-e5e5bba42e51 (accessed 22 January 2018).

Financial Times (2017) UK parcels market nears £10bn in annual turnover. Financial Times, 20 February. Available at: https://www.ft.com/content/eb23f45c-f508-11e6-95ee-f14e55513608 (20.02.17) (accessed 22 January 2018).

Flecker J, Haidinger B and Schönauer A (2013) Divide and serve: the labour process in service value chains and networks. Competition and Change 17(1): 6-23.

Fudge J (2017) The future of the standard employment relationship: labour law, new institutional economics and old power resource theory. Journal of Industrial Relations 59(3): 374-392.

Booth R and Osborne H (2016) 'It's about time': Hermes couriers welcome inquiry into pay. Guardian, 20 October. Available at: https://www.theguardian.com/society/2016/oct/20/itsabout-time-hermes-couriers-welcome-inquiry-into-pay (accessed 22 January 2018).

The Guardian (2018) Supreme court begins hearing plumber's employment case. Available at: https://www.theguardian.com/business/2018/feb/20/supreme-court-begins-hearingemployment-case-pimlico-plumbers-gig-economy-uber (accessed 20 February 2018).

Harvey G, Rhodes C, Vachhani SJ and Williams K (2017) Neo-villeiny and the service sector: the case of hyper flexible and precarious work in fitness centres. Work, Employment and Society 31(1): 19-35.

Harvey M, Quilley S and Beynon H (2002) Exploring the Tomato: Transformations of Nature, Society and Economy. Cheltenham: Edward Elgar Publishing.

Hatfield I (2015) Self-Employment in Europe. London: Institute of Public Policy Research.

Hermann C (2013) The liberalisation of European postal markets and the impact on employment and working conditions. FORBA research report 3/2013. Vienna: FORBA.

Hesse M and Rodrigue J-P (2006) Global production networks and the role of logistics and transportation. Growth and Change: Special Issue on Global Production Networks 32(4): 499509.

HM Government (2018) Good Work: A Response to the Taylor Review of Modern Working Practices. BEIS, February 2018.

Kalleberg AL (2012) Job quality and precarious work: clarifications, controversies, and challenges. Work and Occupations 39(4): 427-448.

Levy K (2015) The contexts of control: information, power and truck driving work. The Information Society 31(2): 160-174.

Moore S and Hayes LJB (2017) Taking worker productivity to a new level? Electronic Monitoring in homecare - the (re)production of unpaid labour. New Technology, Work and Employment 32(2): 101-114.

Moore S and Ross C (2016) Utilising biographical narrative interpretive methods: rich perspectives on union learning journeys and learner motivations. Journal of Education and Work 29(4): 450-469.

Neilson B and Rositer N (2008) Precarity as a political concept, or, fordism as exception. Theory, Culture and Society 25(7-8): 51-72. 
Newsome K (2015) Value in motion: labour and logistics in the contemporary political economy. In: Newsome K, Taylor P, Rainnie A and Bair J (eds) Putting Labour in Its Place: Labour Process Analysis and Global Value Chains. London: Palgrave, 29-45.

Ofcom (2014) Royal Mail Access Pricing Review: Proposed Amendment to the Regulatory Framework. London: Ofcom.

Palier B and Thelen K (2010) Institutionalizing dualism: complementarities and change in France and Germany. Politics and Society 38(1): 119-148.

Pollert A (1988) The flexible firm: fixation or fact. Work, Employment and Society 2(3): 281-316.

Prosser T (2016) Dualization or liberalization? Investigating work in eight European countries. Work, Employment and Society 30(6): 949-965.

Roper J, Ganesh S and Inkson K (2010) Neoliberalism and knowledge interests in boundaryless careers discourse. Work, Employment and Society 24(4): 661-679.

Smith C (2006) The double indeterminacy of labour power: labour effort and labour mobility. Work, Employment and Society 20(2): 389-402.

Strauss K (2017) Towards a geography of precarity? Progress in Human Geography. Epub ahead of print 7 July. Available at: https://doi.org/10.1177/0309132517717786 (accessed 22 January 2018).

Supiot A (2001) Beyond Employment: Changes in Work and the Future of Labour Law in Europe. Oxford: Oxford University Press.

Thompson P and Smith C (2009) Labour power and labour process: contesting the marginality of the sociology of work. Sociology 43(50): 913-930.

Tomlinson D and Corlett A (2017) A Tough Gig? The Nature of Self-employment in 21st Century Britain and Policy Implications. London: The Resolution Foundation.

Vosko LF (2006) Precarious employment: towards an improved understanding of labour market insecurity. In: Vosco LF (ed.) Precarious Employment: Understanding Labour Market Insecurity in Canada. Montreal, QC, Canada; Kingston, ON, Canada: McGill-Queen's University Press, 3-42.

Weil D (2014) The Fissured Workplace: Why Work Became so Bad for so Many and What Can Be Done to Improve It. Cambridge: MA: Harvard University Press.

Sian Moore is Professor of Employment Relations and Human Resource Management and Director of the Work and Employment Research Unit (WERU) at the University of Greenwich. Her research centres on the relationship between gender and class and on trade union organisation and activism. She has also published on unpaid work, focusing upon homecare workers.

Kirsty Newsome is Reader in Employment Relations at Sheffield University Management School. Her research interests are focused around three interconnected core themes: the shifts and transformations in the politics of production; the dynamic interplay of global value chains and the labour process with a particular focus on the logistics sector; and finally the changing dynamics of workplace insecurity.

Date submitted March 2017

Date accepted December 2017 